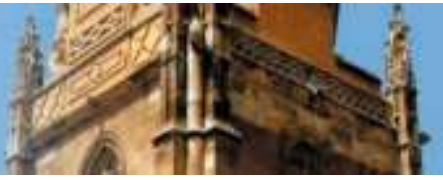

ISSN 1989 - 9572

DOI: 10.47750/jett.2021.12.01.017

\title{
Turkological and Ottomanic legacy of A.Y. Krymsky and Oriental studies in Russia (1896 - 1941)
}

\author{
Ramil M. Valeev ${ }^{1}$ \\ Roza Z. Valeeva ${ }^{2}$ \\ Dinar R. Khayrutdinov ${ }^{3}$ \\ Oksana D. Vasylyuk ${ }^{4}$
}

Journal for Educators, Teachers and Trainers, Vol. 12 (1)

https://jett.labosfor.com/

Date of reception: 10 October 2020

Date of revision: 09 January 2021

Date of acceptance: 08 April 2021

Ramil M. Valeev, Roza Z. Valeeva, Dinar R. Khayrutdinov, Oksana D. Vasylyuk (2021). Turkological and Ottomanic legacy of A.Y. Krymsky and Oriental studies in Russia (1896 - 1941). Journal for Educators, Teachers and Trainers, Vol. 12(1). $132-142$.

${ }^{1}$ Department of Altaic and Chinese Studies, Institute of International Relations, Kazan (Volga Region) Federal University - Kazan, Russia

${ }^{2,3}$ Department of International Languages and Translation Studies, V. G. Timiryasov Kazan Innovative University - Kazan, Russia

${ }^{4}$ A. Krymsky Institute of Oriental Studies, National Academy of Sciences of Ukraine - Kiev, Ukraine 


\author{
Turkological and Ottomanic legacy of A.Y. Krymsky and Oriental studies \\ in Russia (1896 - 1941) \\ Ramil M. Valeev ${ }^{1}$, Roza Z. Valeeva ${ }^{2}$, Dinar R. Khayrutdinov ${ }^{3}$, Oksana D. Vasylyuk ${ }^{4}$ \\ ${ }^{1}$ Department of Altaic and Chinese Studies, Institute of International Relations, Kazan (Volga Region) Federal \\ University - Kazan, Russia \\ ${ }^{2,3}$ Department of International Languages and Translation Studies, V. G. Timiryasov Kazan Innovative \\ University - Kazan, Russia \\ ${ }^{4}$ A. Krymsky Institute of Oriental Studies, National Academy of Sciences of Ukraine - Kiev, Ukraine \\ Email ID: valeev200655@mail.ru, valroz@inbox.ru,dynx27@gmail.com, o_vasylyuk@yahoo.com
}

\begin{abstract}
Research of the Turkic (including Asia Minor), social-political, cultural and ethnolinguistic space of Eurasia is a significant and long-standing tradition of practical and academic research centers of Russia and Europe, including Ukraine. The Turkic (including Ottoman) political and cultural legacy played an especially important role in the history and culture of the peoples of Russia, Ukraine and modern Turkic states. Famous states and societies of the Turkic world (Turkish Khaganates, Volga Bulgaria, the Ulus of Jochi, the Ottoman Empire and other states of the Middle Ages and the modern period), the geographical and historical-cultural areas that were traditionally occupied by Turkic peoples of the Russian and Ottoman empires and Eurasia in general became a subject of academic research done by Russian and European orientalists (experts on Turkic and Ottoman history and culture) of the $19^{\text {th }}$ - early $20^{\text {th }}$ centuries.

A. Y. Krymsky made an enormous contribution into the research of the history and culture of Turkic peoples of Eurasia, and any further studies of his rich academic legacy in Turkology and Ottoman studies during the main periods of his work in Moscow and Kiev remain of great relevance.
\end{abstract}

Keywords: Russia, Ukraine, the East, Turkic peoples, A.Y. Krymsky, Turkology, Ottoman studies, Turkic and Ottoman literature, history, language.

\title{
INTRODUCTION
}

The biography and academic legacy of A.Y. Krymsky was extensively covered in Russian, Ukrainian and, in part, foreign historiography ${ }^{1}$. At the same time further research of his numerous academic works in Turkology and Ottoman studies remains relevant.

In the 18th - early 20th centuries, in the Academy of Sciences and universities of the Russian Empire Turkology and Ottoman studies were a part of the general discipline of Oriental studies, but in addition to being important academic fields on their own they also became the foundation for developing schools of humanities of various peoples of Russia. Their scholarly activities and heritage include a wide variety of scientific, educational, geographical, political and socio-cultural materials about the Turkic socio-political and ethno-cultural world in general and the Ottoman state and society in particular. Their work is a clear evidence of the phenomenon of complexity and interdisciplinarity of Russian Oriental studies, including Turkology and Ottoman studies.

The academic paradigm of Orientalism, which persisted until the first decades of the twentieth century, is very symbolic. The 'Program of the competition for scholars who wish to get the position of an adjunct for Islamic languages and literature in the Imperial Academy of Sciences' (1856) contained a detailed list of requirements for applicants. The applicant had to know "(1) thoroughly the following languages: Arabic, Persian, and Turkish, having an equally thorough knowledge of the history and literature of the three main Muslim peoples. It is desirable, moreover, that he should be informed about Semitic languages in General, particularly Syriac and Ethiopian, and be able to use this information in his scientific research. (2) He should have knowledge of antiquities, especially the numismatics of the Muslim peoples. Finally, (3) it is necessary that he should have proper knowledge of the classical languages and of those of the modern ones that are most necessary in order to follow all the learned researches and discourses about the East." ${ }^{2}$ 


\section{MATERIAL AND METHOD}

The primary methodology of this study is based on the system of various modern principles and ideas philosophical, epistemological and logical ones - that play a defining role in studying trends and objective contents of the history of Oriental studies in Russia and Europe, the centers of academic Asian and African studies of Russia and Europe and the academic heritage of the founders of Oriental education and research. The authors of the paper use a system of methods - both general ones characteristic of Asian and African studies and specific ones borrowed from other social sciences and humanities. The leading methodological principle is the historical or historical-scientific principle based on the involvement of original archival materials.

\section{RESULTS}

In his 'Review of the work of the faculty of Oriental languages' (1909), academician V.V. Bartold assessed the trends and results of the development of Oriental studies of his time (including Turkology and Ottoman studies) and wrote the following: "Of all the regions of the Asian part of Turkey, Asia Minor is of interest not only for orientalists, but also for researchers of the classical world." ${ }^{3}$ Among European researchers of historicalgeographical and cultural studies of the region V.V. Bartold singled out the German philologist and classical archaeologist Ludwig Ross (1806-1859), who had visited Asia Minor in 1844. He also drew attention to the works published in 1839-1848 by French archaeologist and traveler Charles Félix Texier (1802-1871) ${ }^{4}$ and devoted to the history and culture of Asia Minor in general and, in particular, Armenia, Iran and Mesopotamia (his focus was architecture, fine art, historical monuments, urban topography, etc.).

Noting P.A. Tchihatcheff's works on Asia Minor, V.V. Bartold wrote that they, "like other works of this scholar, could not be considered to belong to Russian academic literature"5). Nevertheless, these works became widely known among Russian turkologists and researchers of the Ottoman Empire as well as the Russian public of the second half of the 19th -20 th centuries. ${ }^{6}$

Also V. V. Bartold's attention was focused on the results of studies done by European scholars on archaeological and written artifacts of the classical and modern Asia Minor. At the same time, he emphasized the critical attitude of a number of Russian researchers, including B.A. Turaev, V.F. Minorsky and I.A. Orbeli, to the "methods of "extensive" research" practiced by German expeditions of the first decades of the twentieth century, which, in their opinion, had a negative impact "on the preservation of artifacts that required longer examination"7.

Further, while outlining promising academic tasks related to the research of Asia Minor, V.V. Bartold pointed out the need to continue studying its geography and medieval history "in connection to the history of the Ottoman Empire, which originated from here", which was "yet insufficiently researched". He also noted the importance of decoding the "inscriptions left by the cultured peoples of the ancient East", and researching the little-studied "tongues of Turks of Asia Minor".

Highlighting the phenomenon of the formation of the Turkish national school of history and the historiographical tradition of Kemalist Turkey and summarizing their own specific assessments of the contribution of Turkish researchers to studying of the "past of Turkey", V.V. Bartold noted: "But so far the works of Turkish philologists and historians have not yet shown sufficient familiarity with the methods of European science; especially significant shortcomings are found in the Turkish editions of texts and the catalog of Constantinople manuscripts; this also applies to numerous editions of texts in modern Turkey." ${ }^{8}$

Since its origins, Russian and European Ottoman studies, being a socio-humanitarian discipline and an interdisciplinary branch of Oriental studies, has been organically linked with Turkology, Arabic studies, Iranian studies, Slavic studies and other humanitarian fields. Its subjects are language, literature, history and culture of the Ottoman Empire and its peoples. A clear confirmation of this is the turkological and Ottoman studies heritage of A.Y. Krymsky (1871-1942) (Ahatanhel Yukhymovich Krymsky).

A.Y. Krymsky failed to completely follow the important tradition of Russian and European Ottoman studies of the 19th - early 20th centuries, associated with the systematic stay of researchers and travelers in the Ottoman Empire. He managed to visit the Ottoman Empire only twice - in Lebanon in 1896-1898 and in Trebizond (June - August of 1917) (modern-day Trabzon, Turkey) in the last year of World War I - during a difficult and dramatic period of military and political relations between the Russian and Ottoman empires. During the first year after A.Y. Krymsky moved to Kiev, he published a report on his participation in the academic research expedition in June - August of 1917 led by the Director of the Russian Archaeological Institute, researcher of the Byzantine Empire, F.I. Uspensky (1845-1928) . In his report, A. Y. Krymsky wrote: "Going in strict accordance with the instructions of the head of the expedition, academician F. I. Uspensky, we began to analyze the enormous amount of manuscripts as well as some printed materials that had been collected, immediately after the conquest of Trebizond the previous year, by the efforts of academician F. I. Uspensky in the mosque of Orta Hisar, otherwise Our Lady the Golden-Headed (Chrysokephalos), where the Turks, leaving Trebizond, had already collected a large archive stock in their turn." 10

In a letter dated August 13, 1917, A.Y. Krymsky wrote to the counsellor of the Russian Embassy in Tehran, V.F. Minorsky (1877-1966): "I am in Trebizond sorting (on behalf of the Academy of Sciences) the archive 


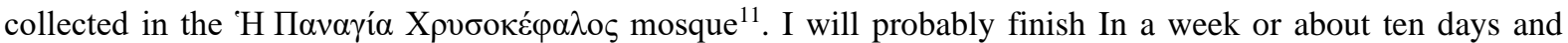
then I will return to Moscow. <...> There is no need to describe what I am seeing in Trebizond. The research results will be published in the report, while as for my personal conclusions <...> well, you have an approximate idea of the state of an occupied city. I think that in Tehran it is about the same as here. Once again, perhaps, I was convinced that we have common interests not with the Greeks, but with the Turks." 12

The first publications of A.Y. Krymsky were literary translations into Ukrainian of famous poetic and other works from Turkish, Persian and Arab literature (Omar Khayyam, Antarah ibn Shaddad, One Thousand and One Nights, etc.). Summarizing the results of the research of song folklore done by European and Russian scholars, A.Y. Krymsky noted: "As we can see, very little has been done so far to study the songwriting works of the Ottoman Turks, and Kunosh, during the eleventh Congress of orientalists, had a good reason to complain about linguists and ethnographers neglecting Ottoman folk songs, as well as all the folklore of the Ottomans in general."13

Preparation and publication of articles called 'Jalal ad-Din Rumi (1207-1263)' (1893) and 'Karagöz' (1895) as well as several other Turkic-themed articles in the 'Encyclopedia of Brockhaus and Efron' in the first half of the 1890s formed and developed a new line of scientific and educational searches for A.Y. Krymsky in the field of Turkology and Ottoman studies. According to A.Y. Krymsky, "Jalal ad-Din Rumi (1207-1263) was the greatest mystical (Sufi) poet of Persia and the entire Muslim world, "the Nightingale of contemplative life". The nickname Rumi means "of Asia Minor"14, and Karagöz is the main figure in the traditional Turkish shadow play or puppet theater. He is a black-eyed ("kara-göz") man, roguish, a lovelace, bearing a significant resemblance to the famous Russian puppet Petrushka or the French Polichinelle. Due to its priapic features, Karagöz constantly falls into thousands of comic and tragicomic positions; the play "Karagöz - a victim of his own chastity" is considered especially comic." 15

Also, during his studies at the Lazarev Institute of Oriental Manuscripts and Moscow University, as well as during the Kiev period of his work A.Y. Krysmky published several historical and cultural articles in the "Encyclopedic Dictionary" and the "New Encyclopedic Dictionary" of Brockhaus and Efron and the "Granat Encyclopedic Dictionary": "Kadin" (1894), "Karagöz" (1895), "Kilij Arslan I", "Kilij Arslan II" (1896), "Mehmed I" (1896), "Namık Kemal Bey" (1897), "Necati" (1897), "Hoca Sadeddin Efendi" (1899), "Seljuqs" (1900), "Tughril Bey" (1901), "Turkish dialects and literatures" (1902), "Fuzuli" (1902), "Aq Qoyunlu" (1911), "Bâkî" (1911), "Vasif Efendi" (1913), "Seljuqs" (1922), "Turks" (1931), "Turkey" (1931), "Turkic literatures" (1931), etc. The last articles by A.Y. Krymsky in the "Granat Encyclopedic Dictionary" were dedicated to the concept of "emir" (ruler / lord in the Arab-Islamic countries) and the famous Persian eulogist poet of the Seljuq era Awhad ad-Din 'Ali Anvari (ca. 1126 - between 1189 and 1191), both published in 1937.

In general, the central position in the academic heritage of the scholar, starting from the Moscow period, was occupied by a variety of translations of works of Turkish poets and prose writers into Ukrainian and Russian, as well as his own artistic writing, which he began creating in 1890. The academic, literary and artistic osmosis of the history and culture of the Ottoman Empire in natural unity with the Arab and Persian political and cultural spaces became an important feature of A. Y. Krymsky's work during the Beirut, Moscow and Kiev periods of his life. Many of his works on the history, literature and culture of Arabs and Persians cover historical events, provide insights into and descriptions of the Ottoman Empire and Turkey.

Important social and political milestones and external criteria in the genesis of academic Turkology and Ottoman studies were the development of the Russian Imperial state and society, primarily the directions and outcomes of the Russian foreign policy in the Middle East and Russian-Turkish wars during the early modern period. In the intra-scientific institutional evolution and typology of university disciplines about Turks, the most important stages are ones associated with the teaching of "Turkish-Tatar and Ottoman literature", the activities of departments and sections of Oriental literature in Russian universities and institutes.

An important place in the history of Oriental studies, including Turkology and Ottoman studies, and in the history and culture of the peoples of Russia, Armenia, Azerbaijan, Kazakhstan, Uzbekistan, Ukraine, etc. is occupied by the key centers of Asian and African studies in Petersburg, Moscow and Kazan - the Asiatic Museum, St. Petersburg, Moscow and Kazan Universities, the Lazarev Institute of Oriental Languages, the Oriental Committee of the Moscow Archaeological Society, the Oriental Division of the Imperial Russian Archaeological Society, and other education and research centers and associations with their rich traditions of research and humanism in studying the Arab-Islamic world and their significant legacy of a lot of prominent scholars and practitioners.

In 1820 - 1835 St. Petersburg University saw the formation of the system of university teaching of the Turkish (Ottoman) language, proposed by O.I. Senkovsky $(1800-1858)$ in 1823, taught "privately and not systematically" and finally approved by the Charter of the University in 1835. According to the University Charter of 1835, teaching of Turkish was officially introduced into the curricula of Russian universities. Poetic, literary and historical works of Turkish authors and "other Ottoman sources" were the training base for professors and teachers in the teaching of Turkish at Russian universities in the first half of the 19th century. "On December 8, 1839, the first independent Department of the Turkish (Ottoman) language was established at 
the University, and it was headed by A.O. Mukhlinsky (1808 - 1877). This event was the beginning of the "systematic teaching of the main turkological disciplines at St. Petersburg University"16. The "sections of Arabic-Persian-Turkish-Tatar literature" at universities became the key institutional base for the development of Russian Turkology and Ottoman studies in the 19th - early 20th century.

In the 1820s - 1830s, an educational and methodological base for teaching the "Turkish-Tatar" language in the First Kazan Grammar School and the Imperial Kazan University was formed, and it was associated with the work of Mirza A. K. Kazem-Bek, in addition to the teaching of the Old Tatar language in these educational institutions by Tatar scholars and educators - representatives of the Khalfin dynasty ${ }^{17}$. In October of 1833 the Kazan school district submitted the "Draft of additional Charter and staff for the First Kazan Grammar School, for teaching Oriental languages in it" to the Ministry of National Education. In his submission, the Trustee of the District in 1827-1845 M.N. Musin-Pushkin (1795-1862) noted that "to Arabic, Persian, Tatar and Mongolian, I added Turkish, finding it, due to the close ties between Russia and Turkey, as necessary as the other languages"18. In 1828 the Section of Oriental Literature of Kazan University included the new Department of "Turkish-Tatar Literature". On August 1, 1845, Mirza Kazem-Bek's half-brother, Abdussatar Kazem-Bek, began teaching a course in the Turkish-Tatar language at the University. In 1828-1854, the Department of TurkishTatar Literature was headed by the following people: until 1846 - A.K. Kazem-Bek (1802-1870), starting from 1846 - Professor in Extraordinary, starting from 1854 Professor in Ordinary I.N. Berezin (1818-1896).

In October of 1835, Professor Alexander Kazem-Bek outlined a plan for compiling "a complete textbook necessary for the successful teaching of the Turkish language in Russia at $\langle\ldots\rangle$ the University and the grammar school." ${ }^{19}$ He planned to compile a grammar, an anthology and a dictionary of the Turkish language within 4 years. The first textbook was to consist of the rules of Turkish grammar. Mirza Kazem-Bek intended to pay special attention "to deviations from these rules existing in other major Turkic dialects, explaining the reasons for such a change as far as possible"20.

Also, since their creation, the curriculums of Kazan and St. Petersburg universities included courses on general history - 'History and Geography of the Ottoman Empire', 'History of Ancient Turkish-Tatar Folk Tribes', 'Political History of the Ottoman State', 'History of Turkey', 'Geography of the Ottoman Empire and Its Constituent Territories', 'Turkish History', i.e. the history of ancient Turkic states and peoples, etc. Particularly in the second half of the 19th - early 20th centuries these university curriculums started using the terms "Ottoman"21 and "Turkish" increasingly often. These 2 terms were used instead of the generalized concept of "Turkish-Tatar", widely used in the first half of the 19th century in the Russian academic Oriental studies.

An equally important scholarly tradition in the history of academic Turkology and Ottoman studies is that of describing Turkish manuscripts and books from various archives and institutions of Russia ${ }^{22}$. In late $1846-$ early 1847 Professor in Extraordinary I.N. Berezin was sent to Moscow to work in the archives of the Ministry of Foreign Affairs in order to review its Oriental funds. He examined materials by F.I. Miller (1705-1783), I.E. Fischer (1697-1771), G.Y. Ker (1692-1740) "on Scythians and Tatars in Latin and German".

In the 19th - early 20th centuries The Lazarev Institute of Oriental Languages was formed as a center for teaching the three main "Muslim" languages, including Turkish. In 1830-1870, especially after the transformation of the Institute in 1848, new directions of research were outlined here, and some important educational, methodological and scientific traditions of studying Turkish were formed. From 1850 onwards L.E. Lazarev (1822-1884), who was invited to the Department of Turkish-Tatar and Persian Literature at the Institute and received a Kandidat Nauk $(\mathrm{PhD})$ degree at Saint Petersburg University (1856), taught classes of Turkish. In the history of Russian and Armenian Turkology and Ottoman studies, he is known as the author of the 'Turkish-Tatar-Russian dictionary of the Ottoman, Crimean and Caucasian dialects, with a brief grammar appendix' (1864) and 'Comparative anthology of the Turkish language of the Osmanli and Aderbijan dialects with an appendix of Turkic conversations and proverbs and their translation into Russian for practical exercises' $(1866)^{23}$.

In 1872-1918, teaching Turkish as well as turkological disciplines and Ottoman studies gained further momentum in the special classrooms of the Lazarev Institute of Oriental languages (LIOL) on the basis of the Department of Turkish-Tatar Language. The library of the Institute's special classrooms had a solid database of books and manuscripts in the languages of the Arab-Islamic world, including ones on the languages, literatures, history and culture of the Turkic peoples and the Ottoman Empire. After L.E. Lazarev's death, the new Professor in Extraordinary at the Department of the Turkish-Tatar Language of the Institute (1884) was a Greek from Asia Minor, S.E. Sakov (1846-1921). He taught courses in Turkish, Azerbaijani, Chagatai, and Sart (1895-1899) to students of the Institute's special classrooms, including the Institute's alumni A.Y. Krymsky (1889-1892) and V.A. Gordlevsky, in addition to teaching classes on Kazan-Tatar texts. In 1901-1906 he published several textbooks in the form of lithographic publications: 'Guide to the study of Turkish. A course of grammar exercises. Part 1' (1901), 'A course of Turkish grammar' (1902) and 'Elements of Turkish grammar' (1906) ${ }^{24}$. From 1885 onwards the course of spoken Turkish in the special classrooms at LIOL was taught by S.G. Tserunian (Dzerunian) (1860-1931). 
Oriental studies, including Turkology an Ottoman studies, as the basic fields of education and research in the Russian university structure of the early modern age were becoming organic components in the implementation of the European ideals of a classical university, in the "rise and expansion of science", "increment in scholarly knowledge", in the development of intellectual capabilities and personal qualities of the students, etc.

The University charters of 1804, 1835, 1863, 1884 developed the institutional bases of the models of classical and applied Turkology and Ottoman studies in the higher educational institutions of Russia. The trend of academic Oriental studies narrowing its focus and creating many niche specialties that continued throughout the 19th century was associated with the requirements of the "pure science", as well as training personnel for state service in the Empire. Russian universities became the most important institutional structure of Turkic and Ottoman studies. In general, the development of academic knowledge about Turkic peoples and the Ottoman Empire in Russian universities was predetermined by various geopolitical, political and cultural factors.

The high domestic and international renown of the Russian school and Russian centers of Turkology and Ottoman studies was largely associated with the research of the classical and modern cycles. There are two key institutional trends in Russian Turkic and Ottoman studies: the traditional approach of regional research and culture studies and the problem-based approach. Both the published and the hand-written legacy of A.Y. Krymsky also testifies to these traditions and innovations.

Russian Turkology was multi-ethnic. In the second half of the 18th century, curriculums of general educational institutions (and in the early 19th century universities as well) began to include Turkic languages. These institutions also expanded the research of the Turkic civilization, problems of state power and institutions of power, popular movements, the history of religions and spiritual systems of Turkic states and societies. The phenomenon of academic Turkic and Ottoman studies in Russia in many ways can be researched in the context of the geopolitical, historical and cultural paradigm of "Russia - Turkic / Ottoman world - West".

An exceptional role in the institutionalization, professionalization and development of humanistic traditions of Turkic and Ottoman studies both in Russia and Ukraine and worldwide was played by A.Y. Krymsky (18711942). Researcher of Middle East and expert in Slavic studies, academic and prominent public figure who possessed encyclopedic knowledge, he made a significant contribution to the history of Arab, Iranian, Turkic and Ottoman studies in Russia, Ukraine and the entire world. The language and literature, history, culture and generally the legacy of the Arab-Islamic civilization, including the Ottoman history and culture, became the primary fields of A.Y. Krymsky's educational activities, research and social work ${ }^{25}$.

A.Y. Krymsky has a very special place in the history of Turkic and Ottoman studies in Russia, Ukraine and around the world. He became a major representative of classical academic Orientalism, including Turkic and Ottoman studies.

Emotional and meaningful works of A.Y. Krymsky on the history and culture of the Turkic peoples, in particular the Turkish ethnic group, are of great interest for understanding the research, achievements and generally intellectual activities of Russian and European turkologists and Ottoman studies experts at the turn of the 20th century and during its first decades.

A.Y. Krymsky's life is often divided into three important periods: the Moscow period (1889-1918), the Beirut period (1896-1898) and the Kiev period (1918-1942). These periods of research, as well as educational and social work of the scholar allow us to identify the main focus areas and fields of his work and the main features of his Turkic and Ottoman studies heritage.

One of Krymsky's first Turkological studies of the Volga-Urals area was the revision of the famous work of N. Ashmarin (1870-1933) 'Essay on literary works of Muslim Kazan Tatars. In 1880-1895' (1901), published in the proceedings of the Lazarev Institute of Oriental Languages ${ }^{26}$. His last work published during his lifetime was devoted to the history and culture of Azerbaijan (1938) ${ }^{27}$.

The first pre-revolutionary turkological (Ottoman) studies of the Moscow period of A.Y. Krymsky's life were his textbooks on the history and culture of the Ottoman Empire: 'From the history of Turkey (from the foundation of the state to the 16th century)' (1909) ${ }^{28}$, 'History of Turkey and its literature from the heyday to the beginning of decline' (1910) ${ }^{29}$, 'History of Turkey. Essay' (1915) $)^{30}$ and 'History of Turkey and its literature. Vol. 1' (1916) ${ }^{31}$. These works, based on a variety of Eastern and European sources and literature, were widely used by the alumni of the Lazarev Institute of Oriental Languages and other Oriental studies centers of Russia. Moreover, they were popular among a wide readership as well. The research done by A.Y. Krysmky on Ottoman literature as well as contemporary Turkish literature became the evidence of continuity of this subject in Russian and Ukranian Turkology. A book called 'Essay on the history of Turkish literature' by V.D. Smirnov ${ }^{32}$ was published as far back as in 1891 .

The results of research of A.Y. Krymsky's turkological and Ottoman studies heritage done by Ukrainian scholars are very significant ${ }^{33}$. In 2007-2010 Krymsky Institute of Oriental Studies of the Academy of Sciences of Ukraine published the scholar's previously published and archival works in a five-volume series of his selected writings ${ }^{34}$.

The key feature of the generalizing Turkic and Ottoman studies conducted by A.Y. Krymsky is that his early works on this subject were consolidated manuals for students of the Lazarev Institute of Oriental Languages, 
and some of his works of that time have been preserved only in manuscript form. In particular, 'Grammar of the Turkish language ${ }^{135}$ and 'Scientific and practical course of Turkish' ${ }^{136}$ were not published.

In the 1918s and 1920s, after A.Y. Krymsky moved to Kiev, a new turn was outlined in his biography in general and in his Turkic and Ottoman research work in particular. It was then that the paradigm he had formulated in a letter to D.I. Bagaley in a letter dated February 2, 1924 became fundamental to him. The quote from that letter is: "My 'History of Turkey' is in half the history of Ukraine." ${ }^{37}$ In the mid-1920s A.Y. Krymsky started preparing a Turkish language course for Ukrainian students. This course, which has been preserved in the manuscript ${ }^{38}$, is interesting because, while presenting the material, the scientist began to shape the Ukrainian scientific terminology.

The key feature of the Turkic and Ottoman studies conducted by A.Y. Krymsky was utmost attention both to original (Eastern, Slavic and Western European) sources and to the array of research literature.

Special attention should be paid to the Kiev stage of turkological and Ottoman studies of A.Y. Krymsky.

In 1924, he published the 'History of Turkey with 13 drawings, taken mostly from old printed editions of the 16th -18th centuries', written in Ukrainian, and in 1926-1932 he published the works 'Introduction to the 'History of Turkey", 'History of Turkey and its writing', 'On the history of Turkish written works of the 16th century' as well as other works related to the Ottoman era ${ }^{39}$.

In 1934-1935 A.Y. Krymsky was preparing to write a major work on the history of new Ottoman literature. Of all he wrote while working on it, only the text called "New Ottoman literature" has survived, and it consists of 12 sheets of typewritten text in Russian and 13 sheets of handwritten text in Ukrainian ${ }^{40}$. In the text, A.Y. Krymsky mentions the significant European influence on Turkish literature and analyzes the works of famous writers, translators, publicists, statesmen and public figures of the Ottoman Empire and the first decades of the Turkish Republic, including Ahmed Vefik Pasha (1823-1891), İbrahim Şinasi (1826-1871), Namık Kemal (1840-1888), Abdülhak Hâmid Tarhan (1852-1937), Recaizade Mahmud Ekrem (1847-1914), Ahmet Mithat (1844-1913).

In the 1930s new publications by A.Y. Krymsky appeared, and these were on the literatures and languages of Turkic peoples of the $\mathrm{USSR}^{41}$, which was largely determined by political and cultural processes that were happening in the Turkic regions and republics of the Soviet Union. In a letter to I.Y. Krachkovsky dated August 20, 1922, A.Y. Krymsky wrote: "When relations were restored in the early 1920s, at least between the regions of the USSR, I was forced by moral necessity to turn a significant force of my energy to the Turkic world, which I was able to have communication with."42 It was in the 1930s that he wrote articles analyzing the history and current state of literature of the Turkic peoples of the USSR and Turkey. The reason for their writing was the need to help the young Soviet Turkic-speaking republics, which did not yet have enough educated academics capable of conducting such research independently. These articles are still relevant today, because they reflect their author's erudition and the profundity of his knowledge ${ }^{43}$.

\section{DISCUSSION}

The research of A.Y. Krymsky's academic heritage, whose integral and important part is his Turkic and Ottoman studies, continues. In the future it is important to publish all of his yet unpublished works and give a complete conceptual and historiographical analysis of A.Y. Krymsky's contribution to Oriental studies.

\section{CONCLUSION}

In the 19th - early 20th centuries the Academy of Sciences and the university centers played a key role in the changing of the status, structure and nature of Oriental studies, and a large contribution to this institutional and research process was made by representatives of the peoples of Russia and Europe - Tatars, Azerbaijani people, Jews, Georgians, Armenians, Polish people, French people, Germans, etc. The multi-ethnic nature of the Oriental studies in Russia is an important humanitarian, social and cultural tradition in this country's scholarly research of the historical and cultural legacy of the East.

Of particular importance are also the search, preparation, and publication of A.Y. Krymsky's epistolary legacy, especially his correspondence with Russian orientalists of the 19th - early 20th centuries: V.R. Rosen, V.V. Bartold, P.K. Kokovtsov, F.E. Korsch, V.A. Zhukovsky, B.V. Miller, V.F. Minorsky and other famous figures of Russian science and culture (A.A. Shakhmatov, V.P. Buzeskul and others).

\section{ACKNOWLEDGEMENTS}

The work has been performed under the Russian Government Program of Competitive Growth of Kazan Federal University, RFBR project № 20-09-00385 A.

\section{REFERENCES}

1. See, for instance: Baziyants, A.P. Lazarevskij institut v istorii otechestvennogo vostokovedeniya [Lazarev Institute in the history of Russian Oriental studies]. - Moscow, 1973; Bartold, V.V. Istoriya izucheniya Vostoka $\mathrm{v}$ Evrope $\mathrm{i}$ Rossii [History of studying the East in Europe and 
Russia]. 2nd ed. - Leningrad, 1925; Dantsig, B.M. Blizhnij Vostok v russkoj nauke i literature: Dooktyabrskiy period [Middle East in Russian Science and Literature: Pre-October Period]. Moscow., 1973; Same author. Izucheniye Blizhnego Vostoka v Rossii (XIX - nachalo XX v.) [Studying the Middle East in Russia (19th - Early 20th Centuries)]. - Moscow, 1968; Same author. Russkiye puteshestvenniki na Blizhnem Vostoke [Russian Travelers in the Middle East]. Moscow, 1965; Dolinina, A.A. Nevol'nik dolga [A slave to duty]. - St. Petersburg, 1994; Istoriya otechestvennogo vostokovedeniya s serediny XIX veka do 1917 goda [The history of Russian Oriental studies from mid-19th century to 1917]. - Moscow, 1997; Kononov, A.N. Biobibliograficheskij slovar' otechestvennyh tyurkologov. Dooktyabrskiy period [Biobibliographical dictionary of Russian turkologists: Pre-October period]. - Moscow., 1974; Gurnitsky, K.I. Agafangel Efimovich Krymsky [Ahatanhel Yukhymovich Krymsky]. - Moscow, 1980, etc.

2. Programma konkursa dlya uchenyh, zhelayushchih zanyat' v Imperatorskoj Akademii nauk mesto ad"yunkta po chasti musul'manskih yazykov i literatury [Program of the competition for scholars who wish to get the position of an adjunct for Islamic languages and literature in the Imperial Academy of Sciences] // Zhurnal Ministerstva narodnogo prosveshcheniya [Journal of the Ministry of National Education]. - 1856. - Part 89. - Section VII. - P. 66.

3. Bartold, V.V. Written works. Vol. IX. Raboty po istorii vostokovedeniya [Works on the history of Oriental studies]. - Moscow, 1977. - P. 342.

4. See: Texier, Charles. Description de l'Asie Mineure; beaux-arts, monuments historiques, plans et topographie des cités antiques (Paris, 1839-1948), Mémoires sur l'architecture et la lythologie anciennes, Edesse et ses monuments en Mésopotamie (1859), Description de l'Arménie, de la Perse et de la Mésopotamie (1845), L'Architecture byzantine (London, 1865).

5. Bartold, V.V. Written works. Vol. IX. Raboty po istorii vostokovedeniya [Works on the history of Oriental studies]. - Moscow, 1977. - P. 473.

6. Tsybulsky, V. A.. P. A. Tchihatcheff - researcher and traveler. - Moscow, 1961; Tsybulsky, V.A. Pyotr Aleksandrovich Tchihatcheff (1808-1890). Platon Aleksandrovich Tchihatcheff (1812-1892) / ed. by A.L. Narochnitsky. - Moscow, 1988, etc.

7. Bartold, V.V. Written works. Vol. IX. Raboty po istorii vostokovedeniya [Works on the history of Oriental studies]. - Moscow, 1977. - P. 343-344.

8. Bartold, V.V. Written works. Vol. IX. Raboty po istorii vostokovedeniya [Works on the history of Oriental studies]. - Moscow, 1977. - P. 345.

9. Otchet [o ekspedicii ot Rossijskoj Akademii nauk dlya ohrany pamyatnikov stariny $\mathrm{v}$ Trapezunde letom 1917 g.] [Report [on the expedition from the Russian Academy of Sciences for the protection of ancient artifacts in Trebizond in the summer of 1917]l // Izvestiya Rossijskoj Akad. nauk. [Bulletin of the Russian Academy of Sciences]. - 1918. - Series 6. - No. 5. - P. 212-216.

10. Otchet [o ekspedicii ot Rossijskoj Akademii nauk dlya ohrany pamyatnikov stariny $\mathrm{v}$ Trapezunde letom 1917 g.] [Report [on the expedition from the Russian Academy of Sciences for the protection of ancient artifacts in Trebizond in the summer of 1917]l // Izvestiya Rossijskoj Akad. nauk. [Bulletin of the Russian Academy of Sciences]. - 1918. - Series 6. - No. 5. - P. 212.

11. Greek: He Panagía Chrysoképhalos - All-Holy [Virgin] the Golden-Headed. The Church of Virgin Mary the Golden-Headed (Panagía Chrysoképhalos) was the place of coronation and burial for Trebizond emperors. Also this Church was where new metropolitan bishops would ascend to their episcopal throne. The church most likely got its name, from the life-size mosaic image of Virgin Mary with a gilded head on one of the pre-altar pillars. In 1461, after capturing the city, the Ottoman Turks turned the church into a mosque.

12. Archive of Orientalists of the Institute of Oriental Manuscripts of the Russian Academy of Sciences. coll. 134. aids 3. fol. 640. p. 1.

13. Krymsky, A.Y. Vstupitel'nyj kritiko-bibliograficheskij obzor. Tureckie narodnye pesni. Muzykal'nye teksty s perevodami i ob"yasneniyami Borisa Millera. [Introductory critical and bibliographic review. Turkish folk songs. Musical lyrics with translations and commentary by Boris Miller]. // Vibrani skhodoznavchi praci: v 5 t. [Selected oriental works: in 5 volumes] Vol. II. Tyurkologiya [Turkology]. - Kiev, 2007. - P. 34.

14. Enciklopedicheskij slovar' [Encyclopaedic dictionary]. Half-volume 19. - St. Petersburg, Brockhaus-Efron, 1893. - P. 248. 
15. Enciklopedicheskij slovar' [Encyclopaedic dictionary]. Half-volume 27. - St. Petersburg, Brockhaus-Efron, 1895. - P. 419.

16. Kulikova, A. M. Stanovlenie universitetskogo vostokovedeniya v Peterburge [The formation of academic Oriental studies in St. Petersburg] - Moscow, 1982. - P. 98.

17. Valeev, R.M. Kazanskoe vostokovedenie: Istoki i razvitie (XIX v. - 20-e gg. XX v.) [Kazan Oriental studies: Origins and development (19th century - 1920s)]. - Kazan, 1998; Valeev, R.M. Orientalistika v Kazanskom universitete (1807 - 20-e gg. XX v.) [Orientalism at Kazan University (1807 - 1920s)]. - Lambert, 2019.

18. State Archive of the Republic of Tatarstan (hereinafter-SA RT). coll. 92. aids 1. fol. 3833. p. 32 back (See: Text of the "Draft Supplement to the Charter of 1828 for the first Kazan Grammar School". SA RT. coll. 92. aids 1. fol. 3833. pp. 34-36.).

19. SA RT. coll. 92. aids 1. fol. 4833. p. 2 back.

20. SA RT. coll. 92. aids 1. fol. 4833. p. 3.

A. Y. Krymsky, explaining the term "Ottoman" used by him, wrote: "I use it in the broadest sense, of course, including here all the dialects of Asia Minor or Anatolia, belonging to the Ottoman state." See: Krymsky, A.Y. Vstupitel'nyj kritiko-bibliograficheskij obzor. Tureckie narodnye pesni. Muzykal'nye teksty s perevodami i ob"yasneniyami Borisa Millera. [Introductory critical and bibliographic review. Turkish folk songs. Musical lyrics with translations and commentary by Boris Miller] // Vibrani skhodoznavchi praci: v 5 t. [Selected oriental works: in 5 volumes] Vol. II. Tyurkologiya [Turkology]. - Kiev, 2007. - P. 29.

21. See: Berezin, I.N. Opisanie turecko-tatarskih rukopisej, hranyashchihsya v bibliotekah S.Peterburga [Description of Turkish-Tatar manuscripts in the libraries of St. Petersburg] // Zhurnal Ministerstva narodnogo prosveshcheniya [Journal of the Ministry of National Education]. - 1846. - Part 50. - No. 5. - P. 33-48; 1847 - Part 54 - No. 5 - P. 33-56; 1848 - Part 59 No. 7. - Section 3. P. 1-24; 1850. - Part 68 - 3. - 12. - Section 3. - P. 13-46; Manuscripts turcs de l'institut des langues orientales decrits par W. D. Smirnow. - St.- Pbg., 1897, etc.

22. Biobibliograficheskij slovar' otechestvennyh tyurkologov. Dooktyabr'skij period [Biobibliographic dictionary of Russian scholars. The pre-Revolution period]. 2nd ed., revised. Prepared by A.N. Kononov. - Moscow, 1989. - P. 141; Baziyants, A.П. Lazarevskij institut v istorii otechestvennogo vostokovedeniya [Lazarev Institute in the history of Russian Oriental studies]. - Moscow, 1973 - P. 71-72, etc.

23. Biobibliograficheskij slovar' otechestvennyh tyurkologov. Dooktyabr'skij period [Biobibliographic dictionary of Russian scholars. The pre-Revolution period]. 2nd ed., revised; prepared by A. N. Kononov. - Moscow, 1989. - P. 208-209.

24. Krymsky, A.Y. Vybrani skhodoznavchi pratsi [Selected Oriental works]: in 5 volumes. Vol. I. Arabistika [Arab studies]. - Kiev, 2007; Krymsky, A.Y. Vybrani skhodoznavchi pratsi [Selected Oriental works]: in 5 volumes. Vol. II. Tyurkologiya [Turkic studies]. - Kiev, 2007; Krymsky, A.Y. Vybrani skhodoznavchi pratsi [Selected Oriental works]: in 5 volumes. Vol. IV. Iranistika [Iranian studies]. - Kiev, 2008; Krymsky, A.Y. Vybrani skhodoznavchi pratsi [Selected Oriental works]: in 5 volumes. Vol. V. Iranistika [Iranian studies]. - Kiev, 2010.

25. Ed.: Ashmarin, N. Ocherk literaturnoj deyatel'nosti kazanskih tatar mohammedan. Za 1880 1895 gg [Essay on literary works of Muslim Kazan Tatars. In 1880-1895]. - Moscow, 1901. IV (Works on Oriental studies published by the Lazarev Institute of Oriental Languages, vol. 4).

26. Krymsky, A.Y. Stranicy iz istorii severnogo ili kavkazskogo Azerbajdzhana (klassicheskoj Albanii). Shcheki [Pages from the history of Northern or Caucasian Azerbaijan (classical Albania). Shaki] // In memory of academician N.Y. Marr (1864 - 1934). - Moscow - Leningrad, 1938. - P. 369 - 384.

27. Krymsky, A.Y. Iz istorii Turcii (Ot osnovaniya gosudarstva do XVI veka). Konspekt lekcij. [From the history of Turkey (from the foundation of the state to the 16th century). Compendium of lectures]. - Moscow, 1909.

28. Krymsky, A.Y. Istoriya Turcii i ee literatury ot rascveta do nachala upadka [History of Turkey and its literature from the heyday to the beginning of decline]. - Moscow, 1910 (Trudy po vostokovedeniyu, izdavaemye Lazarevskim in-tom vostochnyh yazykov [Works on Oriental studies published by the Lazarev Institute of Oriental Languages], vol. 29, no. 1).

29. Krymsky, A.Y. Istoriya Turcii. Ocherk [History of Turkey. Essay] // Tsargrad. Ed. by I. Lazarevsky. - Moscow, 1915. - P. 3-34. 
30. Krymsky, A.Y. Istoriya Turcii i ee literatury. T. 1. (Ot vozniknoveniya do nachala rascveta) [History of Turkey and its literature. Vol. 1. (From the foundation to the beginning of heyday)] Moscow, 1916. - 279 p. (Trudy po vostokovedeniyu, izdavaemye Lazarevskim in-tom vostochnyh yazykov [Works on Oriental studies published by the Lazarev Institute of Oriental Languages], vol. 28-a).

31. Smirnov, V.D. Ocherk istorii tureckoj literatury [Essay on the history of Turkish literature] // Vseobshchaya istorii literatury [General history of literature]. Ed. by V.F. Korsch and A. Kirpichnikov. Vol. IV. - St. Petersburg, 1891. - P. 425-554.

32. Unfortunately, in modern Russian historiography the results and focus areas of A.Y. Krymsky's research of Turkological and Ottoman heritage in Ukranian science of 1990s and 2000s were only fragmentarily known to experts, and even less so to the general readership.

33. Krymsky, A.Y. Vybrani skhodoznavchi pratsi [Selected Oriental works]: in 5 volumes. Vol. II. Tyurkologiya [Turkic studies]. - Kiev, 2007; Krymsky, A.Y. Vybrani skhodoznavchi pratsi [Selected Oriental works]: in 5 volumes. Vol. III. Tyurkologiya [Turkic studies]. - Kiev, 2007.

34. Its manuscript is stored at the Institute of Manuscripts of the Vernadsky National Library of Ukraine (Institute of Manuscripts of the V.I. Vernadsky National Library of Ukraine. coll. I. fol. 25306). Even a superficial examination of this text indicates that A.Y. Krymsky was constantly working to improve it.

35. This course consists of six handwritten notebooks in Ukrainian (Institute of Manuscripts of the Vernadsky National Library of Ukraine. coll. I. fol. 25333).

36. Gurnitsky, K.I. Agafangel Efimovich Krymsky [Ahatanhel Yukhymovich Krymsky]. - Moscow, 1980. - P. 137.

37. Institute of Manuscripts of the Vernadsky National Library of Ukraine. coll. I. fol. 25320. Other handwritten turkological materials also deserve attention (Institute of Manuscripts of the Vernadsky National Library of Ukraine). coll. I. fol. 25336; Institute of Manuscripts of the V.I. Vernadsky National Library of Ukraine. coll. I. fol. 25299. fol. 25338).

38. See: Istoriya Turechchini z 13 malyunkami, shcho ïh uzyato po bil'she iz starodrukiv XVI-XVIII vv. Zvidki pochalasya Osmans'ka Derzhava, yak vona zrostala j rozvivalasya i yak dosyagla apogeyu

39. svoeï slavi $\mathrm{j}$ mogutnosti [History of Turkey with 13 drawings, taken mostly from old printed editions of the 16th -18th centuries. Where the Ottoman Empire began, how it grew and developed and how it reached the apogee of its glory and power]. - Kiev, 1924 (Zbirnik Istor.filol. viddilu VUAN, №10 [Collection of the Historical-Philological Department of the AllUkrainian Academy of Sciences, No 10]); Vstup do istorii Turechchini . Vip. 3. Evropejs'ki dzherela XVI v. [Introduction to the history of Turkey. Vol. 3. European sources of the 16th century] - Kiev, 1926 (Zbirnik Istor.-filol. viddilu VUAN, №10 [Collection of the HistoricalPhilological Department of the All-Ukrainian Academy of Sciences, No 10]); Evropejs'ki dzherela XVI v. dlya istoriï Turechchini (do $1580 \mathrm{rr}$.) [European sources of the 16th century for the history of Turkey (before 1580)] // Zapiski Istor.-filol. viddilu VUAN [Bulletin of the HistoricalPhilological Department of the All-Ukrainian Academy of Sciences]. - 1926. - Books 7-8. - P. 476-488; Hodzha-Nasreddin i jogo «Zharti». Storinka z istoriï turec'kogo pis'menstva XIV-XV vv., yak material dlya fol'kloristiv [Nasreddin Hodja and his "Jokes". A page on the history of Turkish literature of the 14th - 15th centuries as a material for folklorists] // Zapiski Istor.-filol. viddilu VUAN [Bulletin of the Historical-Philological Department of the All-Ukrainian Academy of Sciences]. - 1926. - Books 7-8. - P. 170-180; Istoriya Turechchini ta iï pis'menstva. T. 2. vip. 2. Pis'menstvo XIV-XV vv. [History of Turkey and its writing. Vol. 2. Issue 2. Writing of the 16th 17th centuries]. - Kiev, 1927 (Zbirnik Istor.-filol. viddilu VUAN [Collection of the HistoricalPhilological Department of the All-Ukrainian Academy of Sciences). - No 10. - Vol. 2. - Issue 2); Iz istoriï turec'kogo pis'menstva XIV v. (Z privodu vidannya turec'kogo tekstu poemi «Syuhêil' ve Nevbehâr» 1350-1378 p., shcho opublikuvav J. Mordtman 1925 r.) [From the history of Turkish literature of the 14th century. (On the publication of the Turkish text of the poem "Suheil ve Nevbahar" of 1350-1378, published by J. Mordtman in 1925)] // Zapiski Istor.-filol. viddilu VUAN [Bulletin of the Historical-Philological Department of the All-Ukrainian Academy of Sciences]. - 1927. - Book 10. - P. 313 - 327; Shkola, pis'menstvo j osvita v turec'ko-arabs'kih krayah za peredrevolyucijnoï dobi na grani XIX-XX vv. - Starij skholastichnij musul'mans'kij universitet pri mecheti Azgar u Kaïri [School, writing and education in the Turkish-Arab regions 
during the pre-revolutionary period between the 19th and 20th centuries. - The old scholastic Islamic University at the Al-Azhar Mosque in Cairo] // Krims'kij A. i Bogolyubs'kij O. Do istorii vishchoï osviti u arabiv ta deshcho pro arabs'ku Akademiyu nauk [A. Krymsky and O. Bogolyubsky. On the history of higher education among Arabs and a few words about the Arab Academy of Sciences]. - Kiev, 1928 (Zbirnik Istor.-filol. viddilu VUAN, № 83): Tyurki, ïhni movi ta literaturi [(Collection of the Historical-Philological Department of the All-Ukrainian Academy of Sciences, No 83): Turks, their languages and literatures] // Zapiski Istor.-filol. viddilu VUAN [Bulletin of the Historical-Philological Department of the All-Ukrainian Academy of Sciences]. 1929. - Book 23. - P. 313-351; Tyurkskie literatury i tyurkskie yazyki. Turciya [Istoriya osmans'koï imperiï] [Turkish literatures and Turkic languages. Turkey [History of the Ottoman Empire]]. - Moscow, 1932, etc.

40. Institute of Manuscripts of the Vernadsky National Library of Ukraine. coll. I. fol. 25334.

41. His personal interest to this area of research can be traced in archival materials (Institute of Manuscripts of the Vernadsky National Library of Ukraine. coll. I. fol. 26674).

42. Perepiska akademikov A. E. Krymskogo i I.Y. Krachkovskogo 1920-1930-kh godov [Correspondence of Academicians A.Y. Krymsky and I.Y. Krachkovsky of 1920s-1930s] (Published by I.M. Smilyanskaya // Neizvestnye stranitsy otechestvennogo vostokovedeniya [Unknown Pages of Oriental Studies in Russia]. - Moscow, 1997. - P. 204.

43. For more information, see: Vasilyuk, O.D. Neizvestnye raboty Agafangela Krymskogo po tyurkologii $v$ fondah IR NBUV [Unknown works of Ahatanhel Krymsky on Turkology in the funds of the Institute of Manuscripts of the Vernadsky National Library of Ukraine] / / Skhidnij svit [Oriental world]. - 2013. - No 4. - P. 84-92. Available at: http://nbuv.gov.ua/UJRN/SkhS_2013_4_9; Vasilyuk, O.D. Osobisti paperi Agatangela Krims'kogo $\mathrm{u}$ fondah Institutu rukpisu NBUV [Personal papers of Ahatanhel Krymsky in the funds of the Institute of Manuscripts of the Vernadsky National Library of Ukraine] // Rukopisna ta knizhkova spadshchina Ukraini [Manuscript and book heritage of Ukraine]. 2013. Issue 17. P. 80 - 95; Klimenko, I.V. Ahatanhel Yukhymovich Krymsky // Osobovi arhivni fondi Institutu rukopisu. Putivnik [Personal archival funds of the Institute of Manuscripts. Guidebook]. - Kiev, 2002. - P. 276 - 282; Matveeva, L.V., Chernikov, I.F. Pro tyurkologichnu spadshchinu akademika Agatangela Krims'kogo [On the Turkological heritage of academician Ahatanhel Krymsky] // Krymsky, A.Y. Vybrani skhodoznavchi pratsi [Selected Oriental works]: in 5 volumes. Vol. II. Tyurkologiya [Turkic studies]. - Kiev, 2007. P. 5-26; Chernikov, I. F. Ob issledovaniyah A. E. Krymskogo po turkologii: 20-e gody [On A.Y. Krymsky's research in Turkology: the 20s] // Vostok [Oriens]. -1992. - No 1. - P.104-112, etc. 